\title{
Sun, Sea and Shrines: Application of Analytic Hierarchy Process (AHP) to Assess the Attractiveness of Six Cultural Heritage Sites in Phuket (Thailand)
}

\author{
Sanja Božić ${ }^{A}$, Miroslav D. Vujičić ${ }^{A}$, James Kennell ${ }^{B}$, Snežana Besermenji ${ }^{A}$, Milica Solarević ${ }^{A}$ \\ Received: March 28, 2018 | Revised: May 05, 2018 | Accepted: May 09, 2018
}

DOI: $10.5937 / 22-16983$

\begin{abstract}
In order to make recommendations for the diversification of tourism products on the Thai island of Phuket, this paper applies the analytic hierarchy process (AHP) method to rank the attractiveness of six cultural heritage sites in the island of Phuket to make recommendations for sites that could be incorporated in to cultural tourism development in the region. In addition, it applies a quantitative-qualitative evaluation structure with weighted criteria, based on local expert opinion. The research identified which of the many potential cultural tourism sites would be the most attractive to tourists and shows the utility of the AHP method, combined with quantitative-qualitative evaluation, for decision making in tourism destination development contexts.
\end{abstract}

Keywords: Analytic hierarchy process (AHP); cultural tourism; cultural heritage; diversification; Thailand.

\section{Introduction}

This paper provides an assessment of potential cultural heritage sites for inclusion in a diversified cultural heritage tourism product on the Thai island of Phuket. A significant aim of the research is to combine the analytic hierarchy process (AHP) with the quantitative-qualitative method of cultural site assessment. Doing this allows for the ranking of the assessment factors used in the process according to their importance, as well as the ranking of the cultural sites according to those criteria. Although AHP is widely used in the tourism field, this is the first study that applies AHP in combination with the quantitative-qualitative method of cultural heritage site assessment. The reason for combining these two methods strives from the fact that quantitative-qualitative method of assessment, although being at the same time comprehensive and simple to implement, suggests the equal importance of all assessment criteria. On the other hand, AHP method provides an opportunity to determine the importance of each criterion (by calculating criteria weights and creating a hierarchy), meaning that criteria weight will determine the effect of particular criteria in the overall assessment. For instance, if tourism attractiveness is less important for respondents when assessing the heritage site compared to artistic value, it will have a lower impact on the overall assessment (the procedure is better explained in the methodology and results).

\footnotetext{
A University of Novi Sad, Faculty of Sciences, Department of Geography, Tourism and Hotel Management, Trg Dositeja Obradovića 3, 21000 Novi Sad, Serbia

B University of Greenwich, Old Royal Naval College, Park Row, Greenwich, London SE10 9LS.

* Corresponding author: Sanja Božić; e-mail: sanja.bozic@dgt.uns.ac.rs
} 
Destination experts' opinions on the relative attractiveness of six key cultural heritage sites to cultural tourists were analyzed using this approach. Doing this enabled the making of recommendations for sites which should be developed as part of the island's attempts to diversify its core tourism product away from an over-concentration on the beach and coastal tourism in the destination, which does not consistently support sustainable development in the region (Martin \& Assenov, 2015). As Bravi and Gasca (2014) show, the literature on the development of tourism destinations has tended to focus on the preferences and needs of tourists, and the assessment of the suitability of sites has not featured as prominently. When it comes to complex decisions such as the evaluation of potential tourism sites, which involves a wide range of criteria and alternative options, decision-making becomes a complex process that is reliant on a number of interrelated and interdependent factors, each of which can exert more or less influence over the final decision (Jandrić \& Srđević, 2000). Due to this complexity, specialist software applications - known collectively as Decision Support Systems (DSS) - are increasingly being used to aid in this process. The analytic hierarchy process (AHP) approach, developed by Saaty (1980), is one of the most frequently applied DSS, as well as one of the most extensively used Multi-Crite- ria Decision Making (MCDM) methods. This mathematical method makes use of data gathered through qualitative techniques that draw on the judgment and experience of experts involved in a selection process.

This paper shows how the AHP method can be applied to make decisions about destination development, through a case study of the development of cultural tourism (Du Cros \& McKercher, 2015) in the island of Phuket in Thailand. However, in order to address a criticism of the AHP method, as it is commonly applied, which suggests that the importance of each criterion or indicator that it uses is unrealistically equal in the AHP model, because each possesses its own individual significance and meaning. In order to further investigate the relative importance of the criteria in destination decision making, this study uses a combination of AHP and the quantitative-qualitative method, to provide a hierarchy of factors for assessing cultural heritage according to their importance. Based on this, the study seeks the answers to two most important questions:

1. What is the ranking of criteria for assessing the attractiveness of cultural tourism sites in destinations?

2. How can potential cultural tourism sites in Phuket be ranked, in terms of their potential for inclusion in local cultural tourism development?

\section{Literature Review}

\section{Cultural heritage tourism in Phuket - time for product diversification?}

Thailand was one of the first countries in Asia to develop its tourism industry in a strategic way and it continues to be at the forefront of the international tourism market in the region (Song et al., 2003; Wattanacharoensil \& Schuckert, 2014). In 2016, Thailand received 32,588,00o international arrivals (World Bank, 2017), making an economic contribution of $\$ 82.5 \mathrm{bn}$, or $20.6 \%$ of Gross Domestic Product (GDP), and this is forecasted to rise to $\$ 169.9 \mathrm{bn}$ by 2027 (WTTC, 2017). From the mid-1980s onwards, the Thai Government realized the potential of the tourism industry for contributing to national development priorities (Song, Witt and Li, 2003) and following the Asian Financial Crisis in 1997, the Government again identified tourism as a key source of international currency and investment (Untong et al., 2014). As Cohen and Neal (2010) have identified, the Thai tourism industry has continued to grow at around $6 \%$ per year through a series of further crises caused by various external shocks (Cohen 2008, Saleh et al., 2011) including the 2004 Tsunami, Severe Acute Respiratory Syndrome and Bird Flu, and its reliable contribution to Thai GDP means that it has received consistent policy attention. The Thai government decided to base tourism development on the wide array of natural and cultural resources in the country, especially in southern Thailand. In the late 1980s, recognizing the possibilities and limits for future tourism development, the Thai government engaged the Japanese International Cooperation Agency to create a comprehensive plan for the development of tourism of Southern Thailand (Kontogergopoulos, 1998). This study recognized three tourism development "clusters", one of which was based in Phuket. It emphasized the importance of cultural and historical places as significant tourist attractions, suggesting the opportunity of using cultural and historical heritage in terms of diversification of the tourist product, but concluded that the tourist offer of the region should be based mainly on 3s ("sea, sun, sand") tourism. Phuket was then promoted heavily to international tourists as part of the "Amazing Thailand" campaign of this period (Boonchai \& Beeton, 2015). As a result, the center of tourism in Southern Thailand traditionally continues to be the island of Phuket, situated on the Andaman Sea.

Phuket is Thailand's most popular diving and surfing tourism destination (Biggs et al., 2012; Martin \& 
Assenov, 2015), with its core product based on its tourist beaches (Kontogeorgopoulos, 2004). This island is the location of significant tourism investment and it is the primary center of international tourism development in the region, in part due to the fact that it hosts the country's second largest airport (Smith \& Henderson, 2008). Phuket's tourism product is mainly based on its high concentration of attractions and recreational opportunities, including the attractiveness of its coast, as well as the accessibility of nearby islands. As Cohen (2008) explains, despite the different stages of tourism development of the region since its 'discovery' by Western backpackers in the 1970s, this region of Thailand has been consistently promoted as a 'paradisiac' destination for tourists. The national Thai tourism product has evolved significantly over the past twenty years to include more consideration of cultural and creative tourism opportunities. This is exemplified in the recent Tourism Authority of Thailand (TAT) campaign which aims to promote Thailand as Asia's first creative tourism destination (Wattanacharoensil \& Schuckert, 2014), despite the country's core tourism product continuing to be overwhelmingly coastal and traditional (Nara, Mao and Yen, 2014).

Prideaux et al (2008) explain how the development of tourism in the Asia-Pacific region has led to significant debates about the role of cultural heritage in tourism development in the region, and they identify the management of cultural heritage sites within tourism as a significant theme in research in this location. There have been recent attempts to diversify Phuket's tourism

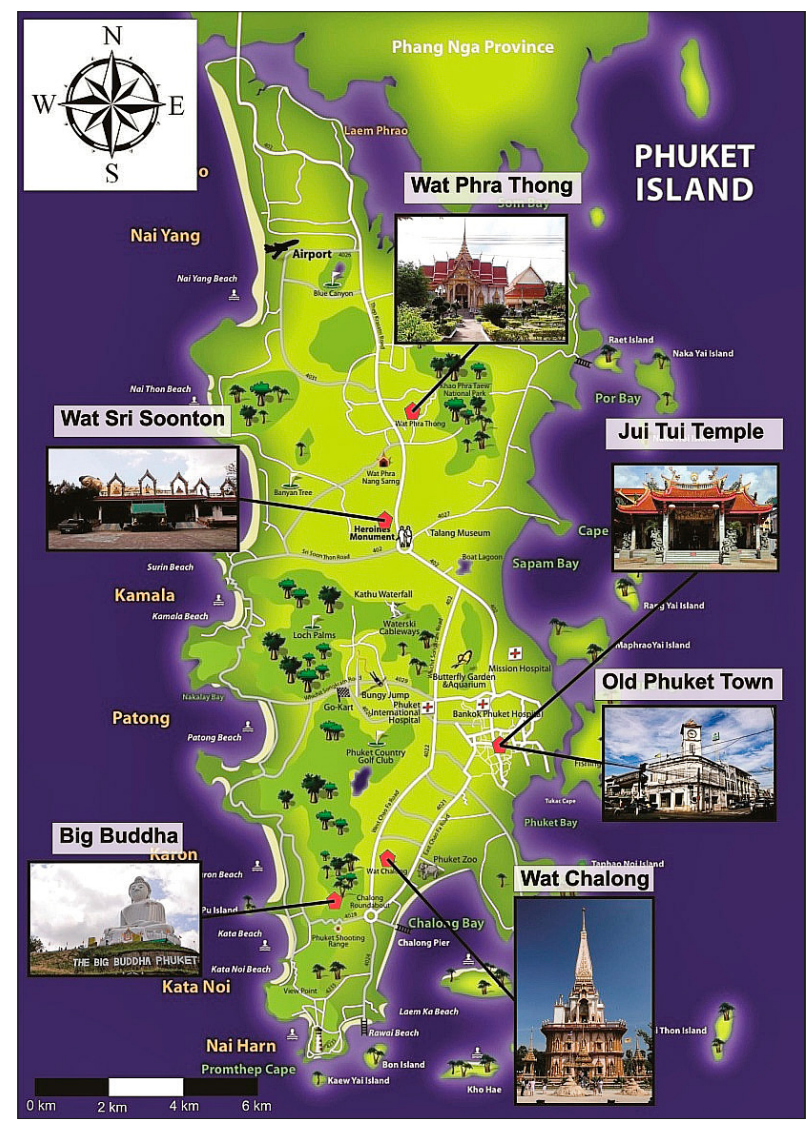

Figure 1. Map of Phuket's most visited Cultural Heritage sites

product including the construction of a convention and events centre, new retail development and the promotion of an emerging spa sector (Sakolnakorn et al., 2013),

Table 1. Phuket's most visited Cultural Heritage sites*

\begin{tabular}{|l|l|l|}
\hline Site No & Cultural site & Description \\
\hline 1. & Big Buddha statue & $\begin{array}{l}\text { This 45- meter- high marble statue is a famous island landmark. Relatively newly built, in } \\
\text { 2004, it is dedicated to the King and it is a popular tourist attraction. This statue is located on a } \\
\text { prominent hill and it is visible from any place in the southern part of Phuket island. It has about } \\
1,500 \text { visitors a day. }\end{array}$ \\
\hline 2. & Wat Chalong & $\begin{array}{l}\text { It is the biggest and the most popular of all Buddhist temples on the island. The importance of } \\
\text { this temple comes from the fact that it houses a relic which is thought to be a piece of Buddha's } \\
\text { bone. }\end{array}$ \\
\hline 3. & Jui Tui temple & $\begin{array}{l}\text { Jui Tui temple is the most popular Chinese temple on the island. Moreover, this temple has } \\
\text { an essential role in the organization of the popular annual Vegetarian festival, which has a } \\
\text { significant impact on the overall number of tourist visits. }\end{array}$ \\
\hline 5. & Sri Soonton temple & $\begin{array}{l}\text { Sri Soonton temple is famous for the 29-meter-high figure of a sleeping Buddha at the top of } \\
\text { the central building of the temple, so large that it can clearly be seen from the road. }\end{array}$ \\
\hline 6. & Wat Phra Thong & $\begin{array}{l}\text { Phra Thong temple is widely known for the golden statue of a Buddha. This temple is also } \\
\text { reputed to be the oldest temple on the island. }\end{array}$ \\
\hline & $\begin{array}{l}\text { This area preserves important cultural heritage assets such as temples and old buildings in } \\
\text { the sino-portuguese style. It provides tourists with the possibility to experience a mixture of } \\
\text { European and Asian influences which have shaped the history of this part of Southern Thailand. } \\
\text { Bearing in mind that 5.3 million tourists visiting Phuket every year, and that almost all of them } \\
\text { visit Phuket town as a central point of the island, we can claim that it is the most visited cultural } \\
\text { heritage site in the island. }\end{array}$ \\
\hline
\end{tabular}

* The sites are selected according to their tourist attractiveness promoted by: the official website of Phuket (www.phuket.com), www. tripadvisor.com and culturetrip.com 
but there has been relatively little emphasis on developing cultural tourism as part of a diversification of the primary tourism product (Sharpley, 2002; Bramwell, 2004; Benur \& Bramwell, 2015), which remains focused on beaches, diving and surfing (Martin \& Assenov, 2015). This is despite the presence of significant cultural heritage sites in the Island, the most visited of which are shown in the table 1 and figure 1.

The six cultural sites described in table 1 are the focus of this paper, which seeks to evaluate their potential as part of the development of cultural heritage tourism in Phuket. Cultural Tourism is defined as "visits by persons outside the host community motivated wholly or in part by interest in historical, artistic, scientific or lifestyle/heritage offerings of a community, region, group or institution" (Silberg, 1995, p. 361 cited in du Cros, 2001). Cultural products are seen as a part of the destination image of Thailand for international tourists (Tavitiyaman \& Qu, 2013) and cultural tourism can be regarded as a more sustainable form of tourism than Phuket's traditional core product, an approach identified as possible for other destinations seeking similar diversification (Wallace \& Russell, 2004; Richards, 2007; Nara et al., 2014; Saarinen et al., 2014, Du Cros \& McKercher, 2015). Cultural tourism forms a more significant part of the core tourism product in other regions of Thailand, for instance in Sakon Nakhon in the north, where the majority of tourism is cultural tourism, based on a similar set of heritage resources (Panich et al., 2014), Bueng Kan, on the border with Laos (Maneteer \& Tran, 2014) and Ayutthaya, the historic capital of Thailand, which is visited by around $10 \%$ of all visitors to the country (Saipradist \& Staiff, 2008). Cultural Tourism is viewed by many destinations as a preferred mode of tourism development because of a range of factors, including its popularity with wealthy baby-boomer generation tourists, a growing sophistication in pre-travel internet searching for destination information by tourists who will be attracted by a destination with cultural features, and cultural tourism's potential to help extend the stay of non-cultural tourists (Wang et al., 2011). Other coastal destinations have also begun to consider diversification strategies in recent years as their traditional product becomes less attractive to postmodern tourism markets (Lacher et al., 2013; Đeri et al., 2017), leading to a restructuring (Agarwal, 2002) of many coastal tourism destinations as they seek to remain competitive, as well as to develop more sustainable forms of local tourism.

Diversification strategies have been researched in many tourism destinations, suffering from a range of problems, including the decline in traditional markets (Schmalleger et al., 2011), sustainability (Farmaki 2012), seasonality (Garau-Vadell \& Borja-Sole 2008) local economic development (Erkus-Ozturk \& Terhhorst, 2015) and as a response to changing macro-economic conditions (Boukas \& Ziakas 2012). Benur and Bramwell (2015) offer a framework for the categorization of tourism development options for destinations seeking to diversify their tourism offer. This framework contains five strategic options, ranked according to their level of diversification and the intensity of their tourism development. The most intense, and least diversified of these options is concentrated mass tourism, where tourists are attracted to a region based on a limited number of high volume tourism products, and in high numbers. This corresponds to the current tourism development situation in Phuket. The alternatives to the concentrated mass tourism model are: Concentrated niche tourism, where a small number of tourism products attract a small number of tourists; Diversified / integrated mass or niche tourism, where corresponding volumes of tourists are attracted by either a range of mass or niche tourism products, which may or may not be integrated into a coherent destination-wide product; and Diversified / integrated mass and niche tourism, where a destination makes use of a range of mass and niche tourism products to attract different types of tourist markets, in varying volumes.

Tourists are increasingly demanding more individualized and authentic forms of tourist experiences, and losing interest in standardized mass tourism products, which coastal mass tourism destination can find it difficult to provide for (Gale, 2005; Viken \& Aarsaether, 2013; Đeri et al., 2017). Sedmak and Mihalic (2008) show that, despite the perception that coastal tourists are content with a limited range of traditional ${ }_{3} \mathrm{~S}$ tourism products, that these tourists do actually express an interest in heritage tourism products. Draper et al., (2012) explain that heritage tourism involves a combination of educational activities and exhibits, tours, artifacts, reenactments, audiovisuals, interactive displays and other resources. Lacher et al. (2013, p. 536) explain how the bringing together of a network of diversified tourism products and services including cultural and heritage resources, can "provide the foundation for building sustained competitive advantage." In addition, diversification through the integration of cultural tourism products can help destinations to reduce the impacts of seasonality, a particularly pressing concern for single-asset destinations (Erkuş-Öztürka \& Terhorst 2018) such as coastal destinations whose primary product is based on sea and sand tourism (Hall 2003, Cisneros-Martínez \& Fernández-Morales, 2015; Zahari et al., 2017). As well as being a traditional coastal destination, Phuket is also one of a kind of mass tourism destination, that has reached maturity in terms of its development, and cultural tourism is often considered to be a "viable 
policy option to implement when a mass tourism destination reaches its maturity stage", as Figini and Vici (2011, p.285) point out in their study of another mass coastal tourism destination, Rimini, in Italy.

\section{The application of AHP for decision making in tourism}

Everybody employed at tourism management positions faces new conditions and is involved in the problem-solving process to embrace new opportunities. Decision making means determining and choosing appropriate options in a short period of time (Hwang \& Yoon, 1981). The first step in decision making is to accept the existence of a problem and then to choose the best solution if there are several of them. Here, the alternatives are evaluated against certain criteria.

The Analytic Hierarchy Process (AHP) is a MultiCriteria Decision Making (MCDM) methodology that is noteworthy for its acceptance of the subjective nature of the information used in many decision-making contexts (Hsu, Lan \& Tsi, 2009). Through its operations, the subjectivities and biases given in individual responses can be factored into the model, allowing for the gradual refinement of decision makingcriteria, which means that is particularly relevant in a tourism development and planning context, where decisions about (for example) resource allocation and promotion can be contested and problematic. In addition, this approach offers a number of advantages in situations where the researcher is interested in assessing a large number of decision factors, measuring the importance of each factor influencing the decision, dealing with factors that vary in terms of their subjectivity and objectivity, and engaging large groups of decision participants to optimize a decision or to evaluate how subgroups of participants vary in their choice behavior (Crouch \& Ritchie, 2005). By using AHP, experts and decision makers are only required to give verbal, qualitative statements regarding the relative importance of one criterion over another. For this reason, the AHP approach can be more accurate than other MCDM methods, which require respondents to express themselves in more complex, pre-determined ways.

Since its introduction, AHP has been applied to tourism in a variety of contexts, where complex decision-making takes place. Mardani et al., (2016), present a systematic review of MCDM techniques and their applications in tourism and hospitality. This study reviewed in total 106 papers published from 1994 to 2014 in 53 peer-reviewed journals. The results of this review indicate that AHP is one of the most frequently used MCDM in tourism and hospitality (in 30.36\% of analyzed papers), where the most researched areas are: location selection, service quality, ecotourism, mar- keting and tourist destinations. This indicates the potential importance of MCDM in problem-solving and decision making in the tourism field. Moreover, the majority of papers using AHP rely on experts' opinion (Tsaur \& Wang, 2007; Göksu \& Kaya, 2014; Chen, 2014; Jordan, 2013), which indicates the suitability of the approach taken in this study.

AHP can assist decision-making in tourism, especially where this involves assessing a large number of decision factors (i.e. factors influencing the choice of destination, motives of destination visit, hotel location selection, tourism indicators), and can measure the importance of each factor influencing the decision. AHP, in so doing, provides a hierarchy of factors according to their importance, which helps managers and other stakeholders to make decisions. The wide applicability of AHP in tourism decision making is shown in the prevalence of this methodology within the tourism literature. For instance, Fabac and Zver (2011) use AHP for making decisions about the future tourist orientation of a region. Huang, Yu, Lou and Zou (2012) propose an evaluation index system of etourism supply chains based on AHP. Papic-Blagojevic et al., (2011) select AHP as a tool for defining tourists' preferences. Božić et al., (2017) applied AHP for assessing urban tourism motivation in Ljubljana, Slovenia. Wickramasinghe and Takano (2010) apply a combination of SWOT and AHP in tourism strategic marketing planning. Park and Yoon (2011) use a combination of Delphi and AHP for the development of sustainable rural tourism evaluation indicators. Chen (2006) implemented the AHP method for convention site selection, while Chou et al., (2008) apply AHP in international tourist hotels location selection. Lai and Vinh (2013) apply AHP in an investigation of tourism promotional effectiveness. Tsaur and Wang (2007) propose an evaluation of sustainable tourism development by using a combination of AHP and fuzzy set theory. Curry and Moutinho (1992) use it when dealing with environmental issues in tourism management. Deng, King and Bauer (2002) also introduce the AHP method in the evaluation of natural attractions for tourism. The use of AHP is also evident in decision-making in cultural tourism. For instance, Ngamsomsuke et al., (2011) use AHP for the development of sustainable cultural heritage tourism indicators. This method helped the authors to rank sustainable cultural heritage tourism indicators according to their importance. Yaolin (2006) use AHP to establish a comprehensive conservation strategy for China's cultural heritage, while Chen and Shi (2009) propose an evaluation on exploitation potential of cultural tourism resources based on AHP. Also, the study of Jordan (2013) applies AHP to identify the built heritage resources of Trinidad and Tobago. 
Within the literature, the AHP method has been combined with several other methods such as SWOT, Delphi, fuzzy set theory and GIS. However, the combination of AHP and the quantitative-qualitative method has not been previously applied in tourism, as a way of involving local experts (stakeholders) in appraising local tourism products, an element of tourism planning that is recommended by Butler et al., (2012) as likely to improve the sustainability of destination development.

\section{The application of AHP and a case study approach}

It is evident that majority of reviewed papers base their research on case studies, as in that way their results can be applied to "real life" situations and problems that occur in tourist destinations and which require complex decision making. A case study approach was chosen for this research because, as Creswell (2007, p.74) claims, a case study approach is appropriate when the "inquirer has clearly identifiable cases with boundaries and seeks to provide an in-depth understanding of the cases or comparison of several cases". Yin (2003, p.1) also indicates that a case study methodology is appropriate when exploratory questions are being posed, when the investigator has little control over events, and when the focus is one a contemporary phenomenon within some real-life context." Botterill and Platenkamp (2012, p.19) describe case studies as „a tried and tested concept in tourism studies”, which is supported by Xiao and Smith (2006) who studied research published in highly ranked tourism journals over a five year period and found that not only were articles based on case studies methods frequently published, that they were not found to be deficient in terms of generalisability or analytical rigor, as they have often been criticised as being. Although single-case study designs such as the one employed in this paper have been criticised for their lack of general generalizability, this has been challenged by many researchers, including Flyvbjerg (2006) who explores how case studies can provide an alternative method of advancing knowledge to standard scientific studies and as a context within which theories can be tested, which is an appropriate description of the approach taken in this paper, which applies a specific MCDM method in a case study. Xiao and Smith (2006, p.747) show that the small-scale, single-case design is most common in tourism research published in the highest ranked journals in the field, concluding that, despite the limitations of case-study design, "case study is not only a frequently used but also a highly useful and much needed approach in tourism research". Papers from the tourism field often apply AHP with a case study approach. For instance, Hsu et al., (2009) apply AHP in exploring the preferences for tourist destina- tion choice in a case study of Taiwan. Wickramasinghe and Takano (2009) apply a combined SWOT and AHP methodology to investigate strategic tourism marketing planning in the case Sri Lanka tourism. Yaolin (2006) uses AHP to establish a comprehensive conservation strategy in the case of China's cultural heritage. In addition, Nekooee, Karami and Fakhari (2011) assess the prioritization of urban tourist attractions using AHP in Iran. They examine the various tourist attractions of Birjand in cultural-historical, man-made and natural dimensions through a multi-criteria assessment method, using the analytic hierarchy process (AHP).

This paper provides a case study of the assessment of potential cultural heritage sites for inclusion in a diversified cultural heritage tourism product on the Thai island of Phuket. The AHP method is considered as the most suitable method for this study, to access the opinion of local stakeholders in cultural tourism on the relative attractiveness of six key cultural heritage sites to cultural tourists. The primary aim is to produce a ranking of these sites according to their attractiveness to tourists, and to indicate the factors that need to be improved in terms of each individual site. Based on this, the authors propose recommendations for sites which should be developed as part of the island's attempts to diversify their core tourism product. In such way, the paper will help local stakeholders and decision-makers to make decisions about which sites to promote as tourism products, in which segments to invest, and to identify priority sites for cultural tourism development in the island of Phuket.

\section{Methodology}

The analytical-hierarchy process (AHP) is a systematic approach developed by Saaty (1980). It provides solutions to complex problems and employs hierarchical structures through developing priorities for different alternatives determined by the decision makers (Brushan \& Rai 2004, p. 15). The AHP approach is used to construct an evaluation model for decision making, using weighted criteria. It integrates different measures into a single overall score for ranking decision alternatives (Hsu, Tsai and $\mathrm{Wu}, 2009$ ). It is usually applied to simplify multiple criterion problems by decomposing it into a multilevel hierarchical structure (Harker \& Vargas, 1987). The goal is placed at the top of the hierarchy, while the criteria, sub-criteria and alternatives are on successive levels and sublevels of the hierarchy (Figure 2). In this paper the potential cultural heritage sites in Phuket represent alternatives in the hierarchy, and indicators of the quantitative-qualitative method of assessment of cultural heritage sites are used as criteria. In the application of this method, the selection of indicators for the as- 
sessment is equally important as the evaluation itself. This study used indicators from the quantitative-qualitative method of assessment of cultural assets developed by Ahmetović (1994), who proposed six main indicators:

1. Microlocation and accessibility - vicinity to tourist areas, vicinity to main communication factors (road, airport, river etc.) and accessibility.

2. Artistic value - Historical importance, rarity, monumentality etc.

3. Scenic/Aesthetic - Proximity to nature, ambient, integration in to the surrounding area etc.

4. Tourist Infrastructure - functional and additional tourism objects (parking space, toilets, interpretive panels etc.)

5. Tourist Appeal - the number of visitors, appeal to tourists etc.

6. Fitting in with other tourist assets in the vicinity Evaluation of other natural and cultural assets in the vicinity.

This model was chosen as it encompasses many important elements for assessing the attractiveness of cultural heritage sites to tourists. Although the model is comprehensive, it is also straightforward (it does not have too many indicators), which make the procedure of evaluating the answers of stakeholders more straightforward and shortens the time required to collect data through interviews. When $n$ criteria exist, the traditional AHP method must conduct $n(n-1) / 2$ pair-wise comparisons between criteria, which might cause confusion to experts due to the many questions that would arise. Consequently, the structured interviews would fail to meet the consistency requirement and would become invalid (Wang \& Chen, 2008). Pairwise comparison of a too large number of indicators makes it difficult for respondents to stay focused and give the well-considered answers, which is why this study has added the indicators developed Ahmetovic to the AHP model.

The AHP model gradually compares alternatives and measures their impact on the final decision-mak- ing goal, which helps decision makers to choose between competing alternatives (Saaty, 1980). Given a pairwise comparison, the analysis involves three tasks: (1) developing a comparison matrix at each level of the hierarchy starting from the second level and working down, (2) computing the relative weights for each element of the hierarchy, and (3) estimating the consistency ratio to check the consistency of the judgment.

Once the hierarchical model of the problem is established, decision makers can compare the elements in pairs at each level of the hierarchy with the element in the higher level of the hierarchy. This means that all alternatives are compared to each other according to defined criteria in the higher level of the hierarchy. The criteria are also weighted, representing a measure of the relative importance of the elements given to them by expert decision makers (Jandrić \& Srđević, 200o). This means that not all criteria have the same importance, but they have different weights. To calculate the weights of $n$ elements, by the comparison of the two elements (i, y), the Saaty's scale (the scale is described in table 3 ).

The result of the comparison of the element $i$ and $y$ is placed in matrix $\mathrm{A}$ in the position a:

$$
\begin{aligned}
& \begin{array}{lllll}
a_{11} & a_{12} & . & a_{1 n}
\end{array} \\
& a_{21} \quad a_{22} \quad . \quad . \quad a_{2 n} \\
& A= \\
& \text {. } \\
& a_{n 1} \quad a_{n 2} \\
& a_{n n}
\end{aligned}
$$

The reciprocal value of the results of the comparison is placed on the position $a_{y i}$ to preserve the consistency of the judgment. The decision maker compares $n$ elements using Saaty's scale (Table 2) and places the results in matrix A (Jandrić \& Srđević, 200o). After all pairwise comparison matrices are formed, the vec-

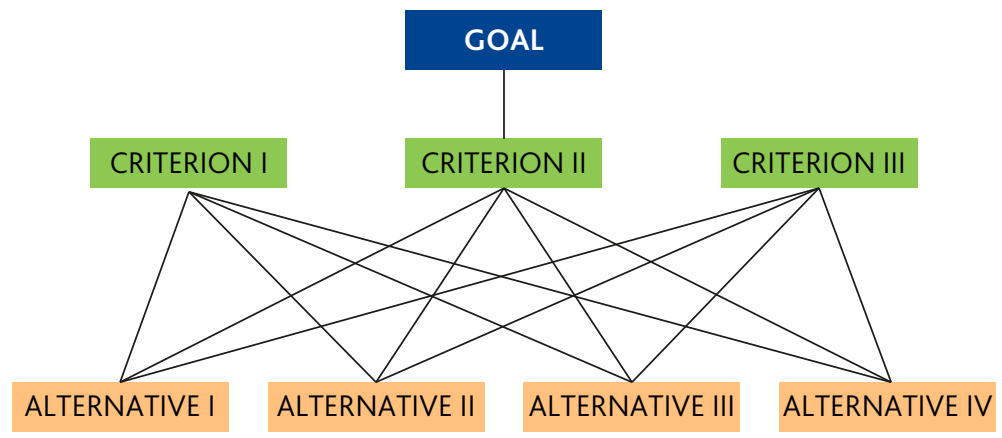

Figure 2. AHP Hierarchical Structure 
tor of weights, $\mathrm{w}=\left[\mathrm{w}_{1}, \mathrm{w}_{2}, \ldots, \mathrm{w}_{\mathrm{n}}\right]$, is computed on the basis of Saaty's eigenvector procedure. The computation of the weights involves two steps. First, the pairwise comparison matrix, $\mathrm{A}=\left[a_{i j}\right]_{n x n}$, is normalized by equation (1), and then the weights are computed by equation (2).

\section{Normalization:}

$$
a_{i j}^{*}=\frac{a_{i j}}{\sum_{i=1}^{n} a_{i j}}
$$

\section{Weights calculation:}

$$
w_{i}=\frac{\sum_{j=1}^{n} a_{i j}^{*}}{n}
$$

for all $i=1,2, \ldots, n$.

Saaty (1980) showed that there is a relationship between the vector weights, $w$, and the pairwise comparison matrix, $\mathrm{A}$, as shown in equation (3).

$$
A_{w}=\lambda_{\text {max }} w
$$

The $\lambda_{\max }$ value is an important validating parameter in AHP and is used as a reference index to screen information by calculating the consistency ratio (CR) of the estimated vector.

It should also be noted that the normalized geometric mean of the rows of the matrix also provides a vector of relative criterion weights, $\{\mathrm{wi}\}$. The vector of criterion weights is then multiplied by criterion weight of the element from the higher level, which was used as a criterion for comparison. This procedure is repeated from the beginning as we go down to the lower levels of the hierarchy. The weight factors are calculated for each element at the given level, and they are then used to determine the so-called composite relative criterion weights of the elements at the lower levels. In the end, the alternative with the highest composite criterion weight is chosen.

From the data, a clear picture of the utility of Ahmetovićs (1994) hierarchy of goals, criterions and alternatives was obtained, shown in figure 3 . On this basis, it was possible to develop results from this approach.

The next phase is the establishment of the consistency of the decision-making process in order to check the reliability of the research. If it were possible to accurately determine the value of criterion weights of all the elements that are compared to each other at the given level of the hierarchy, the eigenvalues of the matrix would be completely consistent. Redundancy of the pairwise comparison makes AHP less sensitive to judgment errors. This model also provides an opportunity to measure the errors in judgment by calculating the index of consistency for the obtained matrix of comparison, after which the ratio of the consistency itself can be measured.

First the consistency index (CI) is calculated according to the formula:

$$
C I=\frac{\lambda_{\max }-n}{n-1}
$$

where $\lambda \max$ is the maximum eigenvalue of the matrix of comparison. The closer $\lambda \max$ is to the number $n$, the smaller the inconsistency will be. At the end the ratio of consistency (CR) can be calculated from the ratio of the consistency index (CI) and the random in$\operatorname{dex}(\mathrm{RI})$ :

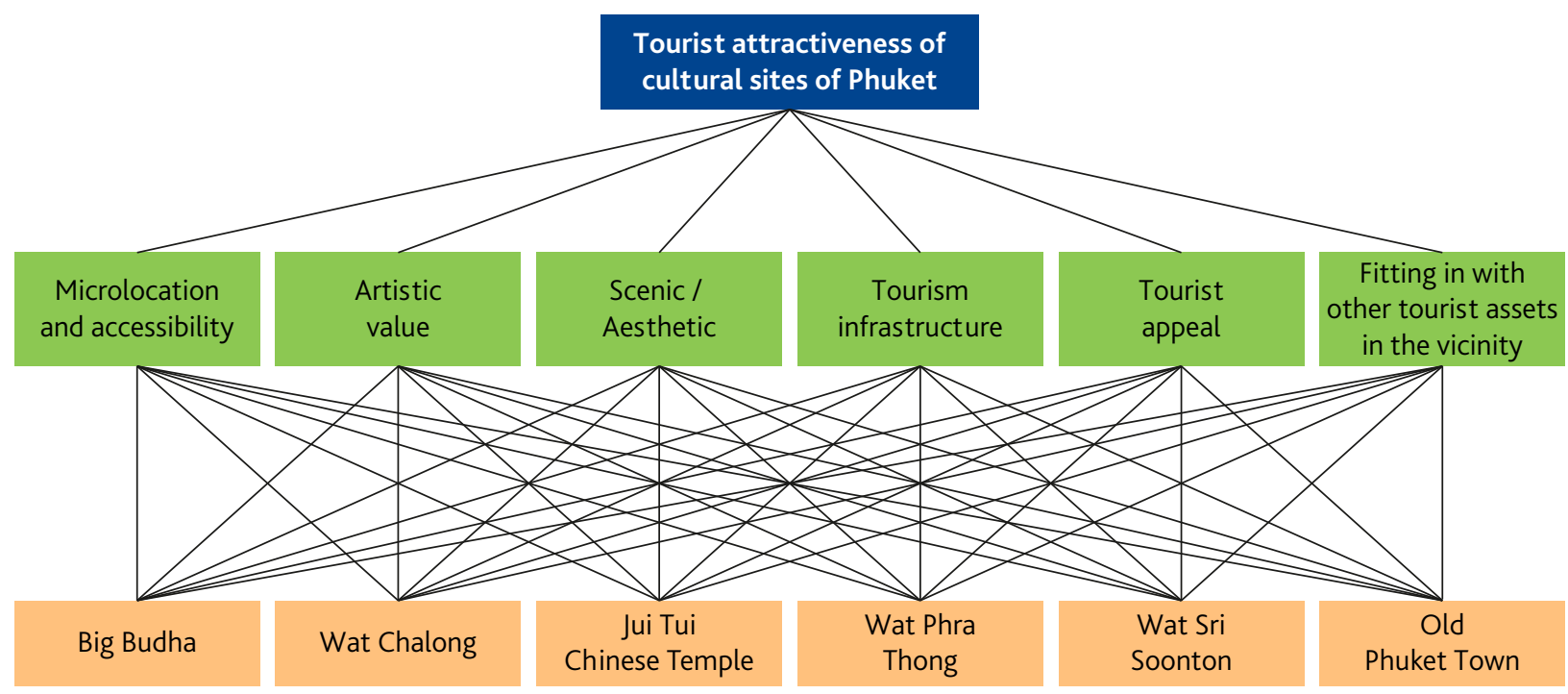

Figure 3. The AHP hierarchy of the current study 


$$
C R=\frac{C I}{R I}
$$

The random index $(R I)$ depends on the row of the matrix (Table 2), where the first row represents the row of the matrix, and the other one represents the random index (details on how to generate random indexes are given in Saaty (1980)). tial tourism product can help to improve the quality of the decision making process and the sustainability of its tourism industry. Many stakeholders' views should be taken into account when developing heritage tourism in a destination to ensure that this is developed in a sustainable way (Ghanem \& Sadd, 2015). This study has made use of expert opinion using the AHP method, a common sampling strategy when using MCDM approaches (Michailidou et al., 2016) that

Table 2. Random index

\begin{tabular}{|c|c|c|c|c|c|c|c|c|c|c|c|c|c|c|}
\hline 1 & 2 & 3 & 4 & 5 & 6 & 7 & 8 & 9 & 10 & 11 & 12 & 13 & 14 & 15 \\
\hline 0.0 & 0.0 & 0.58 & 0.90 & 1.12 & 1.24 & 1.32 & 1.41 & 1.45 & 1.49 & 1.51 & 1.48 & 1.56 & 1.57 & 1.59 \\
\hline
\end{tabular}

Source: Saaty (1980)

If the consistency ratio (CR) is less than o.10, the result is sufficiently accurate and there is no need for adjustments in comparison or for repeating the calculation. If the ratio of consistency is greater than 0.10 , the results should be re-analyzed to determine the reasons for inconsistencies, to remove them by partial repetition of the pairwise comparison, and if repeating the procedure in several steps do not lead to the reduction of the consistency to the tolerable limit of 0.10 , all results should be discarded and the whole procedure should be repeated from the beginning (Jandrić \& Srđević, 2000).

\section{The study sample}

The study was based on the answers of the total of 20 tourism experts in the island of Phuket. The study was conducted in the period from September to January 2013, in the island of Phuket, Thailand. The respondents were approached personally at their workplace (Office of the Tourism Authority of Thailand, Phuket Cultural Centre, Thalang National Museum, Prince Songkla University and Rajabhat University). The sampling strategy for the AHP method can be based on a suitably chosen purposive sample that is appropriate for generating qualitative data, which is useful for research focusing on a specific issue where a large sample is not necessary, especially in tightly bounded case studies (Cheng \& Li, 2002; Lam \& Zhao, 1998). A purposive sampling strategy was deemed appropriate for this research because of the limited need for generalization from the case study (Creswell, 2007). Cheng and Li (2002) argue that AHP method, is in fact, made impractical in surveys with a large sample size as "cold-called", non-expert, respondents may have a great tendency to provide arbitrary answers, resulting in a very high degree of inconsistency, which invalidates the approach (Wong \& Li, 2008).

As Butler et al., (2012) explain, the involvement of local experts in the appraisal of a destination's poten- has been applied in tourism destination development contexts (Richins 2000; Onder et al., 2013; Emir et al., 2016; Do \& Shih 2016). As explained above, the majority of papers using AHP in a variety of fields rely on experts' opinion (Tsaur \& Wang, 2007; Göksu \& Kaya, 2014; Chen, 2014; Jordan, 2013). The major criteria for interviewees selection were education (finished bachelor degree in tourism or cultural management), the work experience (at least 10 years of experience in the tourism industry), job position related to cultural tourism development (including their expert knowledge of the analyzed sites and their specific knowledge about tourism in Phuket). We have now better emphasized this in the paper.

Thus, this research included experts who are employed in different institutions related to the field of cultural tourism, as their diverse knowledge was considered important for making a decision about the relative priority of indicators for tourism assessment, as well as the priority of developing different cultural sites for cultural tourism development. In accordance with this, respondents were selected for this research based on their expert knowledge of the analyzed sites and their specific knowledge about tourism in Phuket. Also, all respondents were important cultural tourism stakeholders in Phuket and included representatives of the Tourism Authority of Thailand, Phuket Cultural Centre, Thalang National Museum, Prince Songkla University and Rajabhat University. The expertise of the respondents was primarily assessed based on their education and work experience. All selected respondents have at least bachelor degree in tourism and their position and place of work are tightly connected with the development of cultural tourism in the island. Correspondingly, all of them have at least 10 years of experience in the tourism industry. The research field and expertise of professors included in this study is cultural tourism and heritage tourism. By providing an expert assessment of these potential tourism sites, 
according to defined criteria, these experts contribute to decision-making about which sites should be the core of cultural tourism diversification in the island of Phuket, as well as to identifying areas needing improvement at individual sites. This is of paramount importance as this analysis could be a basis for developing the strategy of cultural tourism diversification in the island.

At first, 32 key respondents were chosen to participate in this research, but some of them refused to take part in the survey, thus the final sample size included 20 respondents. A sample of this size is consistent with previous studies that have applied the AHP model such as Hsu et al. (2009) who included the views of 32 respondents in the application of AHP for preference analysis for tourist choice of eight destination in Taiwan, while Göksu and Kaya (2014) based research on ranking of tourist destinations in Bosnia and Herzegovina on 12 experts. Chen (2014) used a similar expert questionnaire methodology with sample size of 23 to evaluate the suitability of festivals for inclusion in Taiwan's Tourism and Nation Branding programme, and Tsaur and Wang (2007) carried out research on the evaluation of sustainable tourism development in Green Island in Taiwan, using the view of 16 experts. In an assessment of the suitability of various sites for inclusion in the development of a cultural heritage tourism product in Trinidad and Tobago, with a similar aim to this paper, Jordan (2013) used a similar purposive sample of ten respondents, in order to gather expert opinion. Also, according to Teng (2002) between five and fifteen experts represent a suitable cohort for group decision-making.

\section{Procedure}

The survey was carried out in the form of face-to-face structured interviews. Firstly, respondents were asked to express their preferences, using Saaty's (1980) scale, for Ahmetovics's (1994) criteria, in terms of how important they felt each criterion should be in the evaluation of the attractiveness of a cultural heritage site to potential tourists. The brief explanation of each criterion was provided during the structured interview. We have added the data about time and place where the data were collected. We have also provided an explanation of the problem we have encountered during data collection (see the Procedure chapter): "The major problem the authors encountered during the data collection was the fact that respondents were not familiar with AHP method and the procedure of providing answers in this type of the questionnaire. However, as it was a face-to-face interview, the interviewer explained the method and procedure and clarified the questions. In this way, the interviewer was sure that respondents understand what is expected from them.
Respondents were asked to assign corresponding numerical values based on the relative importance of the attribute (quantitative element), but also to elaborate the reasons why they have given a preference to certain attributes (qualitative element). The qualitative elaboration of the answers was used in order to explain the meaning behind numerical rankings. Afterwards, respondents were asked to express their preferences, using Saaty's (1980) scale, between cultural sites, comparing each site listed in table 1 with another one, thus constructing a pairwise comparison matrix. A small pilot project was carried out before the survey to ensure the reliability of the survey instrument. Due to the fact that the feedback from all of the respondents was satisfactory, the survey was considered to be appropriate and valid for this research.

\section{Questionnaire design and research phases}

The questionnaire was composed of two parts. Part one, consisting of the six criteria, was designed to measure the attributes of the cultural heritage sites. The criteria used for the comparison consists of the basic elements of quantitative-qualitative analysis given by Ahmetović (1994) and described above. Part two consisted of the six alternatives cultural heritage sites, presented in Table 1.

Firstly, respondents compared all of the criteria, according to their importance for the evaluation of tourist attractiveness, giving numerical values to each criterion based on their relevance for each site. Afterwards, the respondents compared all of the cultural sites separately for each criterion, in the same manner previously demonstrated. The answers were measured on Saaty's (1980) scale (from 1 - the same importance, to 9 - the absolute dominance of the element. Reciprocal values were used if the other element has the higher importance, see Table 3).

Table 3. Saaty's scale for pair wise comparisons in AHP

\begin{tabular}{|l|c|}
\hline Judgment term & $\begin{array}{c}\text { Numerical } \\
\text { term }\end{array}$ \\
\hline $\begin{array}{l}\text { Absolute preference (element A over } \\
\text { element B) }\end{array}$ & 9 \\
\hline Very strong preference (A over B) & 7 \\
\hline Strong preference (A over B) & 5 \\
\hline Weak preference (A over B) & 3 \\
\hline Indifference of A and B & 1 \\
\hline Weak preference (A over B) & $1 / 3$ \\
\hline Strong preference (A over B) & $1 / 5$ \\
\hline Very strong preference (A over B) & $1 / 7$ \\
\hline Absolute preference (A over B) & $1 / 9$ \\
\hline
\end{tabular}

An intermediate numerical values 2,4,6,8 and 1/2,1/4,1/6,1/8 can be used as well

Source: Saaty (1980) 
Table 4. Sample answers (Alternatives compared according to microlocation and accessibility)

\begin{tabular}{|c|c|c|c|c|c|c|}
\hline & $\begin{array}{l}\text { Big Buddha } \\
\text { monument } \\
\text { (A) }\end{array}$ & $\begin{array}{c}\text { Wat } \\
\text { Chalong } \\
\text { temple (B) }\end{array}$ & $\begin{array}{c}\text { Jui Tui } \\
\text { Chinese } \\
\text { temple (C) }\end{array}$ & $\begin{array}{l}\text { Wat Phra } \\
\text { Thong } \\
\text { temple (D) }\end{array}$ & $\begin{array}{l}\text { Wat Sri Soonton } \\
\text { (with Reclining } \\
\text { Buddha) (E) }\end{array}$ & $\begin{array}{l}\text { Old Phuket } \\
\text { town (F) }\end{array}$ \\
\hline Big Buddha monument (A) & 1 & 3 & $1 / 9$ & 5 & 7 & $1 / 3$ \\
\hline Wat Chalong temple (B) & & 1 & $1 / 9$ & 3 & 5 & $1 / 5$ \\
\hline Jui Tui Chinese temple (C) & & & 1 & 9 & 9 & 7 \\
\hline Wat Phra Thong temple (D) & & & & 1 & 3 & $1 / 3$ \\
\hline $\begin{array}{l}\text { Wat Sri Soonton (with } \\
\text { Reclining Buddha) (E) }\end{array}$ & & & & & 1 & 7 \\
\hline Old Phuket town (F) & & & & & & 1 \\
\hline
\end{tabular}

A sample answer is shown in Table 4. For example, if alternative A (Big Buddha monument) has absolute dominance compared to alternative $\mathbf{B}$ (i.e. according to micro location and accessibility) we will write 9, but if $\mathbf{C}$ (Jui Tui Chinese temple) has the absolute dominance compared to A (Big Buddha monument), we would write $1 / 9$ (Table 4). In this way, alternatives are compared according to each of the seven criterion (microlocation and accessibility, artistic value, scenic/ aesthetic, tourist infrastructure, tourist appeal, fitting with the other tourist assets in the vicinity).

Data from the structured interviews was entered into the "Expert Choice 2000" statistical software. Expert Choice is decision-making software that is based on multi-criteria decision making and it implements the Analytic Hierarchy Process. Created by Thomas Saaty and Ernest Forman in 1983, the software is supplied by Expert Choice Inc.

\section{Results}

\section{Criterion weighting results}

In Figure 4 the evaluation of the criterion weights by the local experts, giving their ranking according to their assigned importance to tourists, is shown.

The results show that consistency ratio (CR) is 0.08 $(\mathrm{CR}<0.1)$, indicating that the study is reliable and accurate and that therefore there is no need for adjustments in the comparison between criteria. The ranking of the criterion weights (Figure 4) clearly shows that the microlocation and accessibility of the cultural heritage sites included in this study were given the highest criterion weight (o.463) when evaluated by experts, which indicates the great importance of the location, signage and accessibility of cultural sites, in terms of their attractiveness to tourists.

\section{Site ranking results}

Figure 5 shows the expert's relative ranking of each cultural heritage site. From the results of the assessment of the potential cultural tourism sites of Phuket, the Chalong Temple is ranked as the most attractive site in (criterion weight $=0.257$ ). Then, in second place

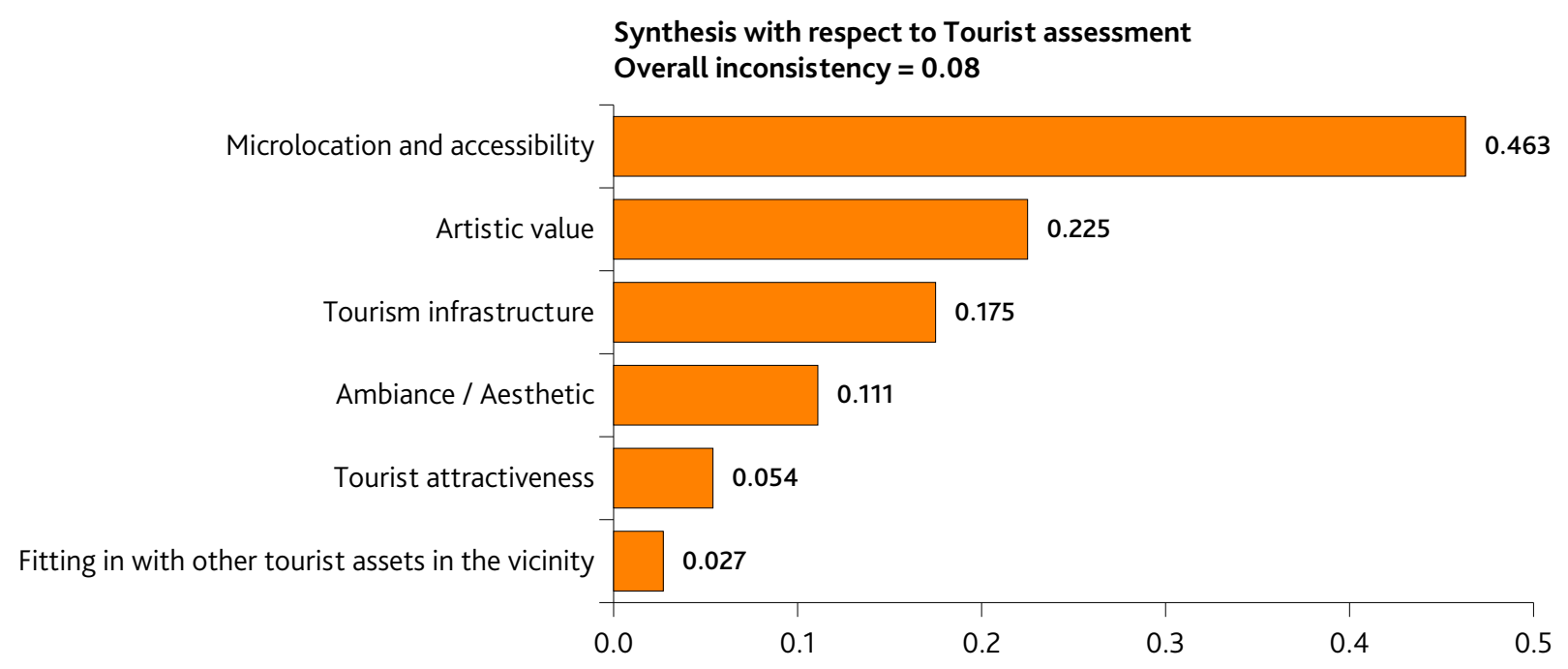

Figure 4. Evaluation of Criteria Weightings 


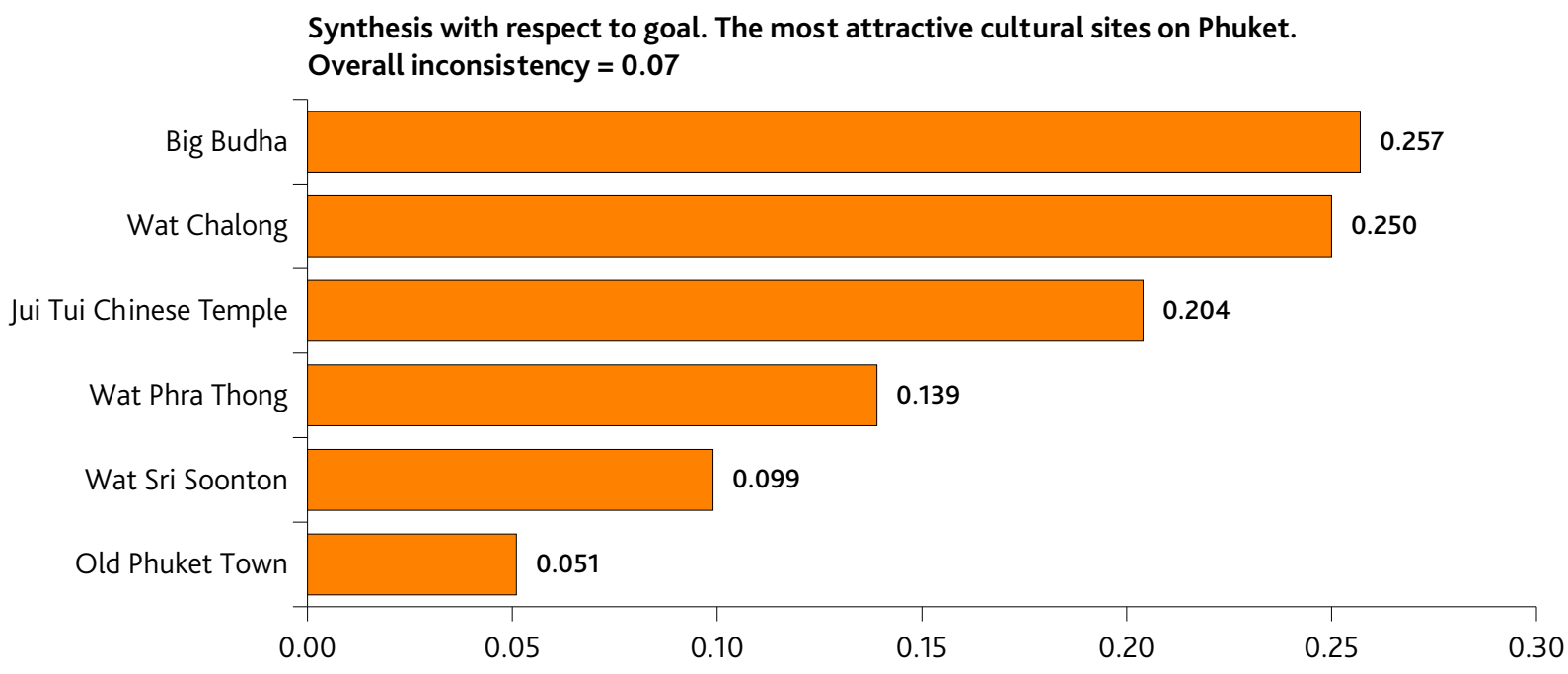

Figure 5. Expert Ranking of Sites

is the Old Phuket Town (0.250), followed by the Big Buddha statue (0.204), JuiTui Chinese Temple (0.139), Phra Thong Temple (o.099), and the cultural site with the lowest ranking is the Sri Soonton Temple (0.051), which is therefore considered to be the least attractive site to potential tourists. The consistency ratio for this section is 0.07 , indicating the reliability of the questionnaire and the results.

The interview responses of the experts who participated in this study add supporting detail to the reasons why the evaluation method has produced these results. There were a lot of reasons given that can explain why the Chalong temple was ranked as the most attractive potential cultural tourism attraction among the numerous cultural heritage sites in Phuket. This temple is reputed to be the most visited among all temples in Phuket (Evans, 2010) as well as the largest Buddhist temple in Phuket (Warren, 2009). Moreover, the temple contains a significant attraction - a relic which is thought to be a piece of Buddha's bone and this makes it a popular destination for visitors (Evans, 2010). The second-ranked potential cultural tourism attraction was the Old Phuket Town, which consists of a number of old streets with interesting buildings (such as Soi Romani), many Chinese and Buddhist temples, as well as numerous parks. The accessibility of the Old Phuket town is very good, as most roads on the island lead to this place, and the signage is excellent as well. The artistic value of the Old Phuket Town is remarkable mainly due to the notable sino-portuguese architectural style, with some of the buildings up to 100 years old (Evans, 2010). Third-ranking belongs to the Big Buddha statue and temple. Due to the fact that it is situated on a hill, it is not so easily accessible to tourists. Only one long winding road leads to this statue, but due to the good signage which indi- cates the direction that leads to the site, it can easily be found. This statue has a great artistic value which lies in the fact that it is made of slabs of white highquality marble which are arranged in a mosaic pattern. According to experts, the ambiance of Big Buddha is breathtaking. The hill on which it is located is also an amazing viewpoint with a stunning view of the three bays of Phuket (Skolnich \& Bush, 2010). Jui Tui Chinese Temple is located in Phuket town, which indicates its very favorable location. Unfortunately, the adequate signage that would indicate the direction to the temple does not exist. The temple is of great importance to Chinese tourists as it is dedicated to the vegetarian god $\mathrm{Ku}$ Wong (Warren, 2009). The Phra Thong Temple, which is the first attraction most visitors encounter when they get to the island, is located next to the main road leading from the airport. There is only one board, indicating the way to the temple, so it is difficult to find. The artistic value lies in the statue of "half-buried" Buddha which is connected with numerous legends, one of which says that anyone who tries to dig it out will die (Evans, 2010). Unfortunately, the complex is neglected and it requires significant investment in reparations and investments to bring it up to the standard required to meet the needs of international tourists, primarily in terms of ambiance and infrastructure. The results indicate that the temple of Sri Soonton was the least attractive potential cultural tourism site among the analyzed cultural heritage sites of Phuket. It is located quite close to the Phra Thong temple, on the main road to the airport. The signage showing the way to this temple hardly even exists, and it is extremely hard to find it even though it is right next to the road. Consequently, there are only a small number of people who have heard of this temple or who have visited it. 


\section{Conclusion}

The main contribution of this study is the application of a combined AHP and quantitative-qualitative method for the assessment of cultural heritage sites, in a destination development context. This methodology provides the answers to important managerial questions: what are the most important criteria for assessing the attractiveness of cultural tourist sites and what are the most attractive cultural sites in the analyzed area, which should be the key sites for cultural tourism development? Firstly, knowing the priority factors in assessing the attractiveness of cultural sites helps decision-makers to focus their investments and develop strategies to support future improvements. Secondly, the comparison of analyzed sites according to defined criteria provides managers with a clear picture of the sites' potential contribution to cultural tourism development in Phuket. Finally, the assessment of the individual sites in this manner represents a possible basis for future development plans for each site, in relation to the criteria that have been identified as the most important by experts.

This paper has considered the role that previously under-used cultural heritage sites could play in a more developed cultural tourism product in the Thai island of Phuket, as part of a product diversification strategy. Since Phuket's tourism development has primarily focused on the development of $3 \mathrm{~S}$ tourism, visiting temples and other cultural sites could represent an additional, complementary tourist offer, described by Benur and Bramwell (2015, p.222) as a strategy of "diversified parallel /integrative mass and niche tourism", appropriate for destinations that have the capacity to support by traditional mass tourism products alongside niche products such as cultural tourism.

The results of this research give a clear picture of the potential of key cultural heritage sites in Phuket for integration into an enhanced cultural tourism product in the island. They provide decision-makers with information on which cultural heritage sites should receive the most attention and be the primary focus of future cultural tourism development in Phuket. Through ranking the weighted selection criteria in terms of their importance, it has been possible to identify the most significant of Ahmetovic's (1994) criteria for the evaluation of the cultural heritage sites in this case study. According to the results, the most important criteria for the evaluation of cultural heritage sites in this case, are shown to be the microlocation and accessibility, followed by the artistic value of these cultural heritage sites. In addition, the results of the assessment show that most of these sites have a favorable location and very signif- icant artistic value which indicates their potential for inclusion in the development of cultural tourism. However, they have not become assets in local tourism development, because there are other factors affecting the sites which have hindered cultural tourism development. These include low levels of investment in infrastructure and signage as well as a lack of restoration and conservation of the objects which have reduced their attractiveness over time. This is in the line with findings of Jordan (2013), who intended to identify the built heritage resources of Trinidad and Tobago. In his study, heritage tourism stakeholders indicate that inadequate legal, institutional and financial frameworks are among the main obstacles hindering the development and growth of this niche market. Moreover, the study of Draper et al., (2012) also emphasized that the financial constraints of heritage tourism sites inhibit the ability to improve programs and services, which is also the case with the analyzed cultural sites in Phuket.

The results of this study should certainly be the basis for planning future improvements in the field of Phuket's cultural tourism, especially because infrastructure and ambiance were also identified as important criteria in this study. As Bravi and Gasca (2014) have shown, the assessment of the suitability of sites for tourism is an under-developed aspect of the literature on destination development, and this paper provides a case study of how the complex decisions involved in selecting sites can be supported using the AHP method. By combining the AHP method (Saaty, 1980) with the quantitative-qualitative method of evaluation for cultural heritage (Ahmetovic, 1994) this study has identified three cultural heritage sites in Phuket with the greatest cultural tourism potential - Phuket Old Town, Wat Chalong and the Big Buddha. The other three sites - JuiTui temple, Wat Phra Thong, Wat Sri Soonton are not currently as attractive for integration into a diversified tourism product offer for Phuket, and this paper also indicates potential areas where this situation can be improved. The results of this study could inform decision making in Thai Destination Management Organizations concerned with developing the Thai tourism product and with diversifying the offer of Phuket, in particular. The combination of the AHP and quantitative-qualitative method of evaluation models for decision making suggest that DSS and MCDM methods have utility for involving local experts in supporting sustainable tourism destination development, although the model will need to apply in a variety of destinations to ensure its reliability. 
This study also has some limitations which should be addressed in the future research. Although the majority of studies using AHP rely only on expert opinion, it is important to also consider demand-side issues in the development of tourist destinations, and the opinion of tourists visiting those sites should also be considered in developing the strategy of cultur- al tourism diversification. Future studies could compare the importance that tourism stakeholders give to certain factors of assessment and those provided by tourists. It is possible that different assessment of factors by those two groups would result in different sites ranking, and this potential gap suggests a fruitful area for future research.

\section{References}

Agarwal, S. (2002). Restructuring seaside tourism. Annals of Tourism Research, 29(1), 25-55. doi:10.1016/ so160-7383(01)00002-0

Ahmetović, T. (1994). Tourism assessment of cultural and historical monuments - Case study Monasteries of Fruška Gora Mountain. Researches Review of the Institute for Geography, Belgrade, 24, 159-172. (In Serbian).

Alberti, F.G., \& Giusti, J.D. (2012). Cultural heritage, tourism and regional competitiveness: The Motor Valley cluster. City, Culture and Society, 3(4), 261273. doi:10.1016/j.ccs.2012.11.003

Alphonce, C.B. (1997). Application of the analytic hierarchy process in agriculture in developing countries. Agricultural Systems, 53(1), 97-112. doi:10.1016/ so3o8-521x(96)0oo35-2

Benur, A.M., \& Bramwell, B. (2015). Tourism product development and product diversification in destinations. Tourism Management, 50, 213-224. doi:10.1016/j.tourman.2015.02.005

Bessière, J. (2013). 'Heritagisation', a challenge for tourism promotion and regional development: an example of food heritage. Journal of Heritage Tourism, 8(4), 275-291. doi:10.1080/1743873X.2013.770861

Biggs, D., Hall, C.M., \& Stoeckl, N. (2012). The resilience of formal and informal tourism enterprises to disasters: reef tourism in Phuket, Thailand. Journal of Sustainable Tourism, 20(5), 645-665. doi:10.1080/ 09669582.2011.630080

Boonchai, C., \& Beeton, R.J.S. (2015). Sustainable Development in the Asian Century: An Inquiry of Its Understanding in Phuket, Thailand. Sustainable Development, 24(2), 109-123. doi:10.1002/sd.1612

Botterill, D., \& Platenkamp, V. (2012). Key Concepts in Tourism Research. London: SAGE Publications. doi:10.4135/9781473914674

Boukas, N., \& Ziakas, V. (2012). Impacts of the Global Economic Crisis on Cyprus Tourism and Policy Responses. International Journal of Tourism Research, 15(4), 329-345. doi:10.1002/jtr.1878

Bramwell, B. (2004). Coastal Mass Tourism: Diversification and Sustainable Development in Southern Europe. Clevedon: Channel View Publications.
Bush, A., \& Skolnich, A. (2010). Phuket encounter. Oakland: Lonely Planet.

Bravi, M., \& Gasca, E. (2014). Preferences Evaluation With a Choice Experiment on Cultural Heritage Tourism. Journal of Hospitality Marketing \& Management, 23(4), 406-423. doi:10.1080/19368623.2013. 822339

Brushan, N., \& Rai, K. (2004). The Analytic Hierarchy Process. Strategic Decision Making Applying the Analytic Hierarchy Process. Springer.

Butler, R., O'Gorman, K.D., \& Prentice, R. (2011). Destination Appraisal for European Cultural Tourism to Iran. International Journal of Tourism Research, 14(4), 323-338. doi:10.1002/jtr.862

Chen, C. (2006). Applying the Analytical Hierarchy Process (AHP) Approach to Convention Site Selection. Journal of Travel Research, 45(2), 167-174. doi:10.1177/0047287506291593

Chen, C. (2014). Suitable Festival Activities for Taiwan's Tourism and Nation Branding with the Application of the PR AHP Program. Asia Pacific Journal of Tourism Research, 19(12), 1381-1398. doi:1 0.1080/10941665.2013.866579

Chen, M., \& Shi, P. (2009). Evaluation on exploitation potential of cultural tourism resources based on AHP - A case of Nanyang jade cultural tourism resources. Journal of Arid Land Resources and Environment, 6, 196-200.

Cheng, E.W.L., \& Li, H. (2002). Construction Partnering Process and Associated Critical Success Factors: Quantitative Investigation. Journal of Management in Engineering, 18(4), 194-202. doi:10.1061/ (asce)0742-597x(2002)18:4(194)

Cisneros-Martínez, J.D., \& Fernández-Morales, A. (2015). Cultural tourism as tourist segment for reducing seasonality in a coastal area: the case study of Andalusia. Current Issues in Tourism, 18(8), 765784. doi:10.1080/13683500.2013.861810

Cohen, E. (1996). Thai tourism: Hill tribes, islands and open-ended prostitution. Bangkok: White Lotus.

Cohen, E. (2008). The Tsunami Waves and the Paradisiac Cycle: The Changing Image of the Andaman Coastal Region of Thailand. Tourism Analysis, 13(3), 221-232. doi:10.3727/108354208786094898 
Cohen, E., \& Neal, M. (2010). Coinciding crises and tourism in contemporary Thailand. Current Issues in Tourism, 13(5), 455-475. doi:10.1080/13683500.201 0.491898

Creswell, J. (2007). Qualitative Inquiry and Research Design: Choosing Among Five Approaches. London: Sage.

Crouch, G.I., \& Ritchie, B.J.R. (2005). Application Of The Analytic Hierarchy Process To Tourism Choice And Decision Making: A Review And Illustration Applied To Destination Competitiveness. Tourism Analysis, 10(1), 17-25. doi:10.3727/1083542054547930

Curry, B., \& Moutinho, L. (1992). Environmental Issues in Tourism Management: Computer Modelling for Judgmental Decisions. International Journal of Service Industry Management, 3(1), 57-69. doi:10.1108/eumooooooooo2811

Man, A.D. (2016). Archaeological heritage and regional development in Portugal. In M.D. Alvarez, F.M. Go, \& A. Yüksel (Eds.), Heritage tourism destinations: Preservation, communication and development. (pp. 142-153). Wallingford: CABI Publishing. doi:10.1079/9781780646770.0142

Deng, J., King, B., \& Bauer, T. (2002). Evaluating natural attractions for tourism. Annals of Tourism Research, 29(2), 422-438. doi:10.1016/so16o7383(01)00068-8

Do, T.H.N., \& Shih, W. (2016). Destination DecisionMaking Process Based on a Hybrid MCDM Model Combining DEMATEL and ANP: The Case of Vietnam as a Destination. Modern Economy, 7(9), 966-983. doi:10.4236/me.2016.79099

Draper, J., OH, C., \& Harrill, R. (2012). Preferences for Heritage Tourism Development Using a Choice Modeling Approach. Tourism Analysis, 17(6), 747759. doi:10.3727/108354212X13531051127267

$\mathrm{Du}$ Cros, H. (2001). A new model to assist in planning for sustainable cultural heritage tourism. International Journal of Tourism Research, 3(2), 165170. doi:10.1002/jtr.297

Cros, D.H., \& McKercher, B. (2015). Cultural Tourism. Abingdon: Routledge.

Evans, C. (2010). Phuket Thailand and Beyond. Montreal: Hunter Publishing Inc.

Emir, O., Bayer, U., Erdoğan, K., \& Karamaşa, Ç. (2016). Evaluating the destination attractions from the point of experts' view: An application in eskişehir. Turizam, 20(2), 92-104. doi:10.5937/turizam1602092e

Erkuş-Öztürk, H., \& Terhorst, P. (2018). Economic diversification of a single-asset tourism city: evidence from Antalya. Current Issues in Tourism, 21(4), 422439. doi:10.1080/13683500.2015.1091806

Fabac, B., \& Zver, I. (2011). Applying the modified SWOT-AHP method of the tourism of Gorn- je Medjimurje. Tourism and Hospitality Management, 17(2), 201-215.

Farmaki, A. (2012). A Supply-Side Evaluation of Coastal Tourism Diversification: The Case of $\mathrm{Cy}$ prus. Tourism Planning \& Development, 9(2), 183203. doi:10.1080/21568316.2011.634431

Figini, P., \& Vici, L. (2012). Off-season tourists and the cultural offer of a mass-tourism destination: The case of Rimini. Tourism Management, 33(4), 825839. doi:10.1016/j.tourman.2011.09.005

Flyvbjerg, B. (2006). Five Misunderstandings About Case-Study Research. Qualitative Inquiry, 12(2), 219-245. doi:10.1177/1077800405284363

Gale, T. (2005). Modernism, Post-Modernism and the Decline of British Seaside Resorts as Long Holiday Destinations: A Case Study of Rhyl, North Wales. Tourism Geographies, 7(1), 86-112. doi:10.1080/1461668042000324076

Garau-Vadell, J.B., \& de Borja-Solé, L. (2008). Golf in mass tourism destinations facing seasonality: a longitudinal study. Tourism Review, 63(2), 16-24. doi:10.1108/16605370810883914

Ghanem, M.M., \& Saad, S.K. (2015). Enhancing sustainable heritage tourism in Egypt: challenges and framework of action. Journal of Heritage Tourism, 10(4), 357-377. doi:10.1080/174387 3Х.2015.1029489

Göksu, A., \& Kaya, S.E. (2014). Ranking Of Tourist Destinations With Multi-Criteria Decision Making Methods In Bosnia And Herzegovina. Economic Review, 12(2), 91-103.

Hall, D. (2003). Rejuvenation, Diversification and Imagery: Sustainability Conflicts for Tourism Policy in the Eastern Adriatic. Journal of Sustainable Tourism, 11(2-3), 280-294. doi:10.1080/09669580308667207

Harker, P.T., \& Vargas, L.G. (1987). The Theory of Ratio Scale Estimation: Saaty's Analytic Hierarchy Process. Management Science, 33(11), 1383-1403. doi:10.1287/mnsc.33.11.1383

Horayangkura, V. (2005). The Future of Cultural Heritage Conservation amid Urbanization in Asia: Constraints and Prospects. Journal of Architectural Research and Studies, 3, 71-82.

Hsu, P., Lan, K., \& Tsai, C. (2013). Selecting the Optimal Vendor of Customer Relationship Management System for Medical Tourism Industry Using Delphi and AHP. International Journal of Enterprise Information Systems, 9(1), 62-75. doi:10.4018/ jeis.2013010104

Hsu, T., Tsai, Y., \& Wu, H. (2009). The preference analysis for tourist choice of destination: A case study of Taiwan. Tourism Management, 30(2), 288-297. doi:10.1016/j.tourman.2008.07.011 
Huang, L., Yu, P., Luo, Q., \& Zou, C.H. (2012). E-tourism supply chain evaluation based on AHP and FCE method. Journal of Theoretical and Applied Information Technology, 45, 702-709.

Hwang, C.L., \& Yoon, K. (1981). Multiple Attribute Decision Making Methods and Applications. Berlin: Springer-Verlag.

Ingram, H., Tabari, S., \& Watthanakhomprathip, W. (2013). The impact of political instability on tourism: case of Thailand. Worldwide Hospitality and Tourism Themes, 5(1), 92-103. doi:10.1108/17554211311292475

Jandrić, Z., \& Srđević, B. (2000). Analytic hierarchy process in selecting best groundwater pond. 31st International Geological Congress, Rio de Janeiro, Brazil.

Jordan, L. (2013). Managing built heritage for tourism in Trinidad and Tobago: challenges and opportunities. Journal of Heritage Tourism, 8(1), 49-62. doi:10 .1080/1743873X.2013.765748

Kaminski, J., Benson, A.M., \& Arnold, D. (2014). Contemporary Issues in Cultural Heritage Tourism, Routledge: Abingdon. (pp. 3-18).

Kontogergopoulos, N. (1998). Tourism in Thailand: Patterns, Trends and Limitations. Pacific Tourism Review, 2, 225-238.

Kontogeorgopoulos, N. (2004). Conventional Tourism and Ecotourism in Phuket, Thailand: Conflicting Paradigms or Symbiotic Partners. Journal of Ecotourism, 3(2), 87-108. doi:10.1080/14724040408668152

Lacher, R.G., Oh, C., Jodice, L.W., \& Norman, W.C. (2013). The Role of Heritage and Cultural Elements in Coastal Tourism Destination Preferences: A Choice Modeling- Based Analysis. Journal of Travel Research, 52(4), 534-546. doi:10.1177/0047287512475215

Lai, W.H., \& Vinh, N.Q. (2013). An application of AHP approach to investigate tourism. Tourism and Hospitality Management, 19, 1-22.

Lam, K., \& Zhao, X. (1998). An application of quality function deployment to improve the quality of teaching. International Journal of Quality \& Reliability Management, 15(4), 389-413. doi:10.1108/02656719810196351

Li, S., \& Li, J.Z. (2009). Hybridising human judgment, AHP, simulation and a fuzzy expert system for strategy formulation under uncertainty. Expert Systems with Applications, 36(3), 5557-5564. doi:10.1016/j.eswa.2008.06.095

Maneenetr, T., \& Tran, T.T. (2014). Developing Cultural Tourism in Border Province: A Case Study on Bueng Kan Province, Thailand. Mediterranean Journal of Social Sciences, doi:10.5901/mjss.2014. v5n23p 55

Mardani, A., Jusoh, A., Zavadskas, E.K., Khalifah, Z., \& Nor, K.M. (2015). Application of multiple-crite- ria decision-making techniques and approaches to evaluating of service quality: a systematic review of the literature. Journal of Business Economics and Management, 16(5), 1034-1068. doi:10.3846/16111699 .2015 .1095233

Martin, S.A., \& Assenov, I. (2013). Measuring the Conservation Aptitude of Surf Beaches in Phuket, Thailand: An Application of the Surf Resource Sustainability Index. International Journal of Tourism Research, 17(2), 105-117. doi:10.1002/jtr.1961

Michailidou, A.V., Vlachokostas, C., \& Moussiopoulos, N. (2016). Interactions between climate change and the tourism sector: Multiple-criteria decision analysis to assess mitigation and adaptation options in tourism areas. Tourism Management, 55, 1-12. doi:10.1016/j.tourman.2016.01.010

McKercher, B. (2016). Towards a taxonomy of tourism products. Tourism Management, 54, 196-208. doi:10.1016/j.tourman.2015.11.008

McKercher, B., Ho, P.S.Y., \& du Cros, H. (2005). Relationship between tourism and cultural heritage management: evidence from Hong Kong. Tourism Management, 26(4), 539-548. doi:10.1016/j.tourman.2004.02.018

Nara, P., Mao, G.G., \& Yen, T.B. (2014). Applying Environmental Management Policy for Sustainable Development of Coastal Tourism in Thailand. International Journal of Environmental Protection and Policy, 2(1), 19. doi:10.11648/j.ijepp.20140201.13

Ngamsomsuke, W., Hwang, T.C., \& Huang, C.J. (2011). Sustainable Cultural Heritage Tourism Indicators. Paper presented at the International Conference on Social Science and Humani, Singapore.

Onder, E., Yildrim, B., \& Ozdemir, M. (2013). Multi Criteria Decision Making Approach for Evaluating Tourism Destinations in Turkey. Academic Journal of Tourism and Management Research, 1, 1-15.

Papic-Blagojevic, N., Gajic, T., \& Djokic, N. (2012). Using Bayesian network and AHP method as a marketing approach tools in defining tourists' preferences. Turizam, 16(1), 8-19. doi:10.5937/turizam12010o8p

Park, D., \& Yoon, Y. (2010). Developing sustainable rural tourism evaluation indicators. International Journal of Tourism Research, 13(5), 401-415. doi:10.1002/jtr.804

Panich, W., Maneenetr, T., Taksina, T., \& Sakolnakorn, T.P.N. (2014). The Management Strategy of Cultural Tourism: A Case Study of Sakon Nakhon Province, Thailand. Asian Social Science, 10(15), doi:10.5539/ass.v10n15p48

Phuket Municipality. (2002). Old Phuket: Our Heritage, The Development and Conservation of Old Commercial Quarter in Phuket Town. Commemoration of the 5th Old Phuket Town Festival, 21-22, December 2002. 
Poria, Y., Butler, R., \& Airey, D. (2003). The core of heritage tourism. Annals of Tourism Research, 30(1), 238-254. doi:10.1016/s016o-7383(02)ooo64-6

Prideaux, B., Timothy, D., \& Chon, K. (2008). Themes in Cultural and Heritage Tourism in Asia and the Pacific. In B. Prideaux, D. Timothy, \& K. Chon (Eds.), Cultural and Heritage Tourism in Asia and the Pacific. Abingdon: Routledge.

Quattrone, G. (2015). Combined management strategies for the valorisation and reuse of defence cultural heritage and the promotion of sustainable cultural tourism. In O. Ozcevik, C.A. Brebbia, \& S.M. Sener (Eds.) WIT Transactions on Ecology and the Environment (pp. 953-962). Southampton, UK: Witpress LTD. doi:10.2495/sdp150801

Richards, G. (2001). The development of cultural tourism in Europe. In G. Richards (Ed.), Cultural attractions and European tourism. (pp. 3-29). Wallingford: CABI Publishing. doi:10.1079/9780851994406.0003

Richards, G. (2007). Global Trends in Cultural Tourism. In G. Richards (Ed.), Cultural Tourism: Global and Local Perspectives. Abingdon: Routledge.

Richins, H. (2000). Local Government Tourism Decision-Making: A study of authoritative opinion. Journal of Tourism Studies, 11(2), 2-14.

Saipradist, A., \& Staiff, R. (2008). Crossing the Cultural Divide: Western Visitors and Interpretation at Ayutthaya World Heritage Site, Thailand. Journal of Heritage Tourism, 2(3), 211-224. doi:10.2167/jhto61.o

Saarinen, J., Moswete, N., \& Monare, M.J. (2014). Cultural tourism: new opportunities for diversifying the tourism industry in Botswana. Bulletin of $G e$ ography. Socio-economic Series, 26(26), doi:10.2478/ bog-2014-0041

Saaty, T.L. (1977). A scaling method for priorities in hierarchical structures. Journal of Mathematical Psychology, 15(3), 234-281. doi:10.1016/00222496(77)90033-5

Saaty, T.L. (1992). Presidential Elections, the Superconducting Supercollider, and Organ Transplant Decisions. In A. Goicoechea, S. Zionts, \& L. Duckstein (Eds.), Multiple Criteria Decision Making. (pp. 345-358). New York, NY: Springer Nature. doi:10.1007/978-1-4612-2918-6_27

Sakolnakorn, T.P.N., Naipinit, A., \& Kroeksakul, P. (2013). Sustainable Tourism Development and Management in the Phuket Province, Thailand. Asian Social Science, 9(7), doi:10.5539/ass.v9n7p75

Saleh, A.S., Verma, R., \& Ihalanayake, R. (2011). Do External Shocks Have a Permanent or a Transitory Effect on Thailand's Tourism Industry. Tourism Analysis, 16(4), 483-491. doi:10.3727/10835421 1X13149079789098

Santos, M.C., Ferreria, A.M., \& Cosat, C. (2014). Influential factors in the competitiveness of mature tourism destinations. Tourism and Management Studies, 10(1), 73-81.

Saaty, T.L., \& Kearns, K.P. (1980). The Analytical Hierarchy Process: Planning, Priority Setting, Resource Allocation. In Analytical Planning. (pp. 19-62). New York: McGraw-Hill.

Schmallegger, D., Taylor, A., \& Carson, D. (2011). Rejuvenating Outback Tourism through Market Diversification: the Case of the Flinders Ranges in South Australia. International Journal of Tourism Research, 13(4), 384-399. doi:10.1002/jtr.851

Sedmak, G., \& Mihalič, T. (2008). Authenticity in mature seaside resorts. Annals of Tourism Research, 35(4), 1007-1031. doi:10.1016/j.annals.2008.07.004

Sharpley, R. (2002). Rural tourism and the challenge of tourism diversification: the case of Cyprus. Tourism Management, 23(3), 233-244. doi:10.1016/so2615177(01)0oo78-4

Smith, R.A., \& Henderson, J.C. (2008). Integrated beach resorts, informal tourism commerce and the 2004 tsunami: Laguna Phuket in Thailand. International Journal of Tourism Research, 10(3), 271-282. doi:10.1002/jtr.659

Song, H., Witt, S.F., \& Li, G. (2003). Modelling and Forecasting the Demand for Thai Tourism. Tourism Economics, 9(4), 363-387. doi:10.5367/000000003322663186

Su, S., Yu, J., \& Zhang, J. (2010). Measurements study on sustainability of China's mining cities. Expert Systems with Applications, 37(8), 6028-6035. doi:10.1016/j.eswa.2010.02.140

Tavitiyaman, P., \& Qu, H. (2013). Destination Image and Behavior Intention of Travelers to Thailand: the Moderating Effect of Perceived Risk. Journal of Travel \& Tourism Marketing, 30(3), 169-185. doi:10.1 o8o/10548408.2013.774911

Teng, J.Y. (2002). Project evaluation: Methods and applications. Keelung, Taiwan: National Taiwan Ocean University.

Timothy, D.J., \& Boyd, S.W. (2006). Heritage Tourism in the 21st Century: Valued Traditions and New Perspectives. Journal of Heritage Tourism, 1(1), 1-16. doi:10.1080/17438730608668462

Tourism Authority of Thailand. (2015). Media Release 24th June 2015: Thailand Visitor Arrivals Surge 25\% in Jan-May. Thailand. Available at: http://www.tatnews.org/thailand-visitor-arrivals-surge-25-in-janmay-2015/ (Accessed 29th March 2016).

Tsaur, S., \& Wang, C. (2007). The Evaluation of Sustainable Tourism Development by Analytic Hierarchy Process and Fuzzy Set Theory: An Empirical Study on the Green Island in Taiwan. Asia Pacific Journal of Tourism Research, 12(2), 127-145. doi:10.1080/10941660701243356 
Untong, A., Ramos, V., Kaosa-Ard, M., \& ReyMaquieira, J. (2014). Thailand's Long-Run Tourism Demand Elasticities. Tourism Economics, 20(3), 595-610. doi:10.5367/te.2013.0280

Viken, A., \& Aarsaether, N. (2013). Transforming an Iconic Attraction into a Diversified Destination: The Case of North Cape Tourism. Scandinavian Journal of Hospitality and Tourism, 13(1), 38-54. doi: 10.1080/15022250.2013.771994

Wallace, G., \& Russell, A. (2004). Eco-cultural tourism as a means for the sustainable development of culturally marginal and environmentally sensitive regions. Tourist Studies, 4(3), 235-254. doi:10.1177/1468797604057326

Wang, T., \& Chen, Y. (2008). Applying fuzzy linguistic preference relations to the improvement of consistency of fuzzy AHP. Information Sciences, 178(19), 3755-3765. doi:10.1016/j.ins.2008.05.028

Wang, S., Yamada, N., \& Brothers, L. (2010). A Case study: discussion of factors and challenges for urban cultural tourism development. International Journal of Tourism Research, 13(6), 553-569. doi:10.1002/jtr.826

Warren, W. (2009). Phuket: Pearl of the Orient. Singapore: Periplus Editions.

Wattanacharoensil, W., \& Schuckert, M. (2016). Reviewing Thailand's master plans and policies: implications for creative tourism. Current Issues in
Tourism, 19(10), 1045-1070. doi:10.1080/13683500.20 14.882295

Wickramasinghe, V., \& Takano, S. (2010). Application of Combined SWOT and Analytic Hierarchy Process (AHP) for Tourism Revival Strategic Marketing Planning: A Case of Sri Lanka Tourism. Journal of the Eastern Asia Society for Transportation Studies, 8, 954-969.

World Bank. (2017). International Tourism, Number of Arrivals. Available at: http://data.worldbank.org/ indicator/ST.INT.ARVL?locations=TH (Accessed 17th May 2017).

Wong, J.K.W., \& Li, H. (2008). Application of the analytic hierarchy process (AHP) in multi-criteria analysis of the selection of intelligent building systems. Building and Environment, 43(1), 108-125. doi:10.1016/j.buildenv.2006.11.019

WTTC. (2017). Travel and Tourism Economic Impact: Thailand. London: World Travel and Tourism Council.

Xiao, H., \& Smith, S.L.J. (2006). Case studies in tourism research: A state-of-the-art analysis. Tourism Management, 27(5), 738-749. doi:10.1016/j.tourman.2005.11.002

Yaolin, Z. (2006). An application of the AHP in cultural heritage conservation strategy for China. $\mathrm{Ca}$ nadian Social Science, 2, 16-20. 